\title{
The decision to drop the case in the new EPPO's regulation: Res ludicata or transfer of competence?
}

New Journal of European Criminal Law 2019, Vol. 10(2) 186-199 (C) The Author(s) 2019 Article reuse guidelines: sagepub.com/journals-permissions DOI: 10.1 177/203228441986022। njecl.sagepub.com

(SAGE

\section{Michele Caianiello}

University of Bologna, Italy

\begin{abstract}
This article discusses one of the most important decisions the European Public Prosecutor's Office (EPPO) can take: the decision to drop a case. When this happens, the case will either be referred to national prosecutors or to the European Anti-Fraud Office (OLAF) or dismissed entirely. Why is this an important decision? Because it means the EPPO declines to prosecute, prosecution being (along with investigation) its very raison d'être. This is why it is important to understand how and when the EPPO may drop a case. In this respect, the EPPO Regulation (adopted on 12 October 2017) pursues two goals: first, it seeks to leave the EPPO a certain margin of discretion when deciding whether to drop a case; secondly, however, it seeks to limit that discretion in order to reduce the risk of decisions that are arbitrary or based on irrelevant considerations. This article argues that this strikes an acceptable balance between two different legal traditions: the ones inspired by the strict legality principle, such as Italy and Germany, and those inspired by the principle of opportunity, such as France or England and Wales. The article further explores how this balance is consistent with the emerging principles of international criminal law, where international tribunals try the most serious crimes only.
\end{abstract}

\section{Keywords}

European Public Prosecutor's Office, decision to dismiss, res iudicata, transfer of competence, criminal investigations, EU financial interests

\section{Introductory remarks}

On 12 October 2017, after 20 years of debates and proposals, the Council of the European Union (EU) finally adopted the regulation establishing the European Public Prosecutor's Office (EPPO)

\section{Corresponding author:}

Michele Caianiello, Department of Legal Studies, University of Bologna, Via Zamboni 27/29, 40I26 Bologna, Italy. E-mail: michele.caianiello@unibo.it 
pursuant to the enhanced cooperation procedure provided by Article 86(1) TFEU. ${ }^{1}$ This regulation gives birth to the first EU office purely dedicated to criminal law enforcement. Whereas Eurojust ${ }^{2}$ is an agency fundamentally founded on enhancing judicial cooperation between Member States, the EPPO will be required, when it assumes its investigative and prosecutorial tasks, ${ }^{3}$ to directly conduct investigations and prosecute before national courts those responsible for crimes affecting the financial interests of the EU.

The aim of this article is to examine one of the most important decisions the EPPO can take: the decision to drop a case and to either refer it to national prosecutors or to the European Anti-Fraud Office (OLAF) or to dismiss it entirely. The importance of this decision arises from the fact that it amounts to the EPPO declining to prosecute, prosecution being (along with investigation) its very raison d'etre. How that decision is taken is therefore critical. The criteria the EPPO applies in deciding to drop a case must not leave an unreasonable risk of leading to impunity, particularly given the importance to the EU of the interests EPPO seeks to protect, including protection of the EU's financial interests. At the same time, the closure of an investigation must fully respect both the rights of the defendant and the interests and right to be heard of the complainants. In other words, the policy followed and the criteria applied by the EPPO in deciding whether to drop a case is a critical facet of the rule of law in the EU's supranational level.

When considering this question, one's attention is immediately drawn to Article 39 of the EPPO Regulation. It is this Article which provides that a case shall be dismissed when any one of a number of conditions - which are rather common in relevant national law - are met, such as the death of the suspect, a lack of evidence, amnesty, immunity, ne bis in idem or the expiry of the national statutory limitation period. ${ }^{4}$ However, limiting the analysis to this provision would be misleading. In a multilevel system such as EPPO, an institution that is founded on the principle of subsidiarity contained in Article 5 TEU, it is necessary to focus on two other aspects. The first is the referral of a case to national prosecutions. Precisely because the EPPO system must operate so as to respect the principle of subsidiarity, an appropriate division of labour between the supranational and the national levels will be necessary. Put in other terms, in examining EPPO's dismissal decisions, we must also look at the provisions permitting the EPPO to leave a case to national prosecutors - an option that de facto can often be used even where a case is simply dropped by the

1. Council Regulation (European Union) 2017/1939 of 12 October 2017 implementing enhanced cooperation on the establishment of the European Public Prosecutor's Office ('the EPPO') [2017] OJ L283/1. So far, 20 member states have joined the enhanced cooperation: Austria, Belgium, Bulgaria, Croatia, Cyprus, Czech Republic, Estonia, Germany, Greece, Spain, Finland, France, Italy, Latvia, Lithuania, Luxembourg, Portugal, Romania, Slovenia and Slovakia.

2. Council Decision 2009/426/JHA of 16 December 2008 on the strengthening of Eurojust and amending Decision 2002/ 187/JHA setting up Eurojust with a view to reinforcing the fight against serious crime [2009] OJ L138/14.

3. According to Article 120 of the Regulation, the EPPO shall assume the investigative and prosecutorial tasks conferred on it by the Regulation 'on a date to be determined by a decision of the Commission on a proposal of the European Chief Prosecutor once the EPPO is set up'. The date to be set by the Commission shall not be earlier than 3 years after the date of entry into force of the Regulation.

4. Article 39(1) of the EPPO Regulation reads: 'Where prosecution has become impossible, pursuant to the law of the Member State of the handling European Delegated Prosecutor, the Permanent Chamber shall, based on a report provided by the European Delegated Prosecutor handling the case in accordance with Article 35(1), decide to dismiss the case against a person on account of any of the following grounds: (a) the death of the suspect or accused person or winding up of a suspect or accused legal person; (b) the insanity of the suspect or accused person; (c) amnesty granted to the suspect or accused person; (d) immunity granted to the suspect or accused person, unless it has been lifted; (e) expiry of the national statutory limitation to prosecute; (f) the suspect's or accused person's case has already been finally disposed of in relation to the same acts; (g) the lack of relevant evidence'. 
EPPO. ${ }^{5}$ The second aspect to take into consideration concerns the existence and extent of a bar deriving from a decision to drop the investigation or to refer it to national prosecutors. Once the case has been dropped or referred, can the EPPO reopen it? And if so, under what conditions? The EU Court of Justice has, on various occasions in recent years, intervened to solve analogous problems which emerged in the context of judicial cooperation between the Member States. One can reasonably expect that similar troubles will arise in the EPPO system because of its nature as an integrated and multilevel prosecutorial system. This is particularly true given the drafting of the final version of the EPPO Regulation, which is inspired - perhaps too much - by the principle of subsidiarity and which aims to preserve the role of national prosecutors at the expense of having a strong centralized structure.

In this article, I will begin with some preliminary considerations on the structure of the EPPO, considering in particular how this evolved from the Commission's July 2013 proposal. I will then focus firstly on the criteria the EPPO Regulation sets out for referring a case to national prosecutors or OLAF and for the dismissal of case. Third, I will analyse how far such a decision prevents the EPPO itself, national prosecutors or OLAF from reopening a case. In particular, I will analyse how far the principle of ne bis in idem applies in such a case.

\section{An acceptable compromise?}

In the EPPO system, while the provisions concerning decisions to dismiss a case have not considerably changed from the Commission's original proposal, ${ }^{6}$ the same cannot be said in relation to those concerning decisions to refer a case to national authorities. As explained in the following, the latter provisions in the EPPO Regulation differ substantially from the 2013 proposal. It is helpful to start by considering the overall aim of these sets of provisions. In general terms, the balance they strike appears to pursue two goals. On the one hand, the EPPO should enjoy a margin of discretion when deciding whether to drop a case. In other words, the legislature declined to subject the EPPO to the strict principle of legality with regard to whether, how and where to prosecute or not. Under that principle, applied in Italy and Germany among others, any case that constitutes a crime within the jurisdiction of the prosecutor must be prosecuted, subject only to strict exceptions provided by law. That the legislature declined to do this is especially evident if we consider decisions on how and, most of all, where (i.e. before which court and by which prosecutor) to prosecute, not merely whether to do so. On the other hand, this margin of discretion should not be unlimited. On the contrary, it should be subject to a scrutiny, in order to avoid the risk of decisions that are arbitrary

5. Article 39 itself confirms this point, providing at para 2 that 'Where the EPPO is competent in accordance with Article 22(3), it shall dismiss a case only after consultation with the national authorities of the Member State referred to in Article 25(6). If applicable, the Permanent Chamber shall refer the case to the competent national authorities in accordance with Articles 34(6), (7) and (8)'. This provision makes clear that decisions to drop cases on the one hand, and decisions to refer them to national authorities on the other, are considered alike, or at least very similar.

6. For a general overview on the various proposals on the EPPO, see L. Hamran and E. Szabova, 'European Public Prosecutor's Office: Cui Bono?', New Journal of European Criminal Law 4(1-2) (2013), pp. 40-58. See also M. Zwiers, The European Public Prosecutor's Office, Analysis of a Multilevel Criminal Justice System (Cambridge-AnterwerpPortland: Intersentia, 2011). See also, with regard to other proposals concerning the EPPO, A. Klip, 'The Substantive Criminal Law Jurisdiction of the European Public Prosecutor's Office', European Journal of Crime, Criminal Law and Criminal Justice ((EJCCL) 20 (2012), pp. 367-376. See further, on the EPPO generally, S. White, 'Towards a Decentralised European Public Prosecutor's Office', New Journal of European Criminal Law (NJECL) 4(1-2) (2013), pp. 22-39 et seq. 
or based on irrelevant considerations. A third factor overlays those two goals, namely that of subsidiarity: the EPPO should focus only on the most serious cases, leaving other ones to national prosecutors or other EU authorities (such as OLAF).

This balance constitutes an elegant compromise between two different legal traditions. The first applies the strict legality principle, as can be seen in countries such as Italy, Portugal and Germany, even though in the latter case the principle is described in a slightly different way. The second applies the principle of opportunity, as in the cases of France, England and Wales. ${ }^{7}$ It moreover resonates with the emerging principles of international criminal law, whereby international criminal jurisdictions 'share' cases (and the resource use those entail) with national prosecutors and courts, the international jurisdiction trying only the most serious cases. ${ }^{8}$

A further angle should be noted. In some cases, the EPPO may take into account a costs/benefits assessment in deciding how to prosecute and engage in some forms of bargaining. In particular, Article 40 of the EPPO Regulation allows the EPPO to dispose of a case pursuant to a 'simplified prosecution procedure [...] on the basis of terms agreed with the suspect' where national law provides for one.

Finally, the EPPO's decision to dismiss a case entirely gives rise to only a limited estoppel, preventing further prosecution by the EPPO unless new evidence or facts justify reopening the case. However, in certain cases, the dropping of a case gives rise to a fuller estoppel, barring further subsequent prosecution under the ne bis in idem principle (such as, e.g. when the case is closed with a plea agreement).

\section{The Commission's Proposal v. the Regulation: Two (very) different structures}

The Commission Proposal ${ }^{9}$ envisaged a simpler framework than that ultimately adopted in the EPPO Regulation. ${ }^{10}$ First, the EPPO as envisaged in the proposal had a vertical, cost-efficient structure $^{11}$ and was decentralized with most operative powers in the field to be exercised by the

7. See on the matter the book edited by E. Luna and M. Wade, Transnational Perspectives on Prosecutorial Power (USA: Oxford University Press, 2012).

8. As the former President of the International Criminal Court, Philip Kirsch said, ' $[\mathrm{t}]$ he Court itself is the judicial pillar ... The other pillar of the ICC Statute - the enforcement pillar - has been reserved to states and, by extension, to international organizations'. See International Criminal Court, ICC President, Judge Philippe Kirsch, addresses United Nations General Assembly. Available at: https://www.icc-cpi.int/en_menus/icc/press $\% 20 \mathrm{and} \% 20 \mathrm{media} / \mathrm{press} \% 20 \mathrm{releases} /$ 2007/Pages/icc\%20president\%20\%20judge\%20philippe\%20kirsch\%20\%20addresses\%20united\%20nations\%20general \%20assembly.aspx (accessed 1 November 2007). See also W.A. Schabas, 'Prosecutorial Discretion and Gravity', in C. Stahn and G. Sluiter, eds., The Emerging Practice of the International Criminal Court (Leiden: Koninklijke Brill, 2009), p. 229.

9. See Commission Document 2013/0255, Proposal for a Council Regulation on the establishment of the European Public Prosecutor's Office. The text of the proposal can be found here. Available at: https://ec.europa.eu/transparency/ regdoc/rep/1/2013/EN/1-2013-534-EN-F1-1.Pdf (accessed on 24 June 2019). See, on the Commission's Proposal, L. Bachmaier Winter, 'The Potential Contribution of a European Public Prosecutor in Light of the Proposal for a Regulation of 17 July 2013', European Journal of Crime, Criminal Law and Criminal Justice (EJCCL) 23(2) (2015), pp. $121-144$

10. See Council Regulation (EU) 2017/1939 of 12 October 2017 implementing enhanced cooperation on the establishment of the European Public Prosecutor's Office.

11. See M. Caianiello, 'The Proposal for a Regulation on the Establishment of an European Public Prosecutor's Office: Everything Changes, or Nothing Changes?', European Journal of Crime, Criminal Law and Criminal Justice (EJCCL) 2 (2013), pp. 115-125. See also K. Ligeti and M. Simonato, 'The European Public Prosecutor's Office: Towards a 
European Delegated Prosecutors (EDPs). However, the EDPs were required to act under the exclusive authority of the European Public Prosecutor (EPP) and to follow the EPP's instructions, guidelines and decisions alone in carrying out the investigations and prosecutions assigned to them. Moreover, looking at the working of the central office, the EPP's Deputies were required to operate under the EPP's direction and supervision, who further retained the power to exercise his or her authority directly (Article 6(4)). Furthermore, where EDPs were also national prosecutors, the EPP could instruct them to EPPO investigations and prosecutions. Finally, according to Article 18(5) and (6), the EPP could reallocate a case to another EDP or take over the investigation and prosecution. This hierarchical relationship between the EPPO's central office and the EDPs is confirmed by the 2013 proposal's provisions concerning the appointment and dismissal of EPPO members. While the EPP and their Deputies were politically elected (by the Council with the consent of the European Parliament), the EDPs were appointed by the EPP themselves from list of three candidates submitted by each Member State. Further, the EPP could dismiss an EDP if they considered that the EDP no longer fulfilled the requirements for appointment established by the proposal. $^{12}$ Together and individually, these features gave the EPPO envisaged by the Commission a decidedly hierarchical, not collegial, structure. The opposite holds true for the EPPO Regulation as ultimately adopted. The EPPO is envisaged as a collegial, strongly decentralized structure (Article 8(1-2)). National authorities do not only exercise operational power; the Supervising European Prosecutor (SEP) and EDP also take many of the decisions, at least in the first instance. The SEP and EDP are both selected, by different procedures, from the Member State where the investigations take place.

\section{The provisions concerning the deferral of the case to national prosecutors}

\section{The 2013 Commission Proposal}

The provisions governing the EPPO's referral of a case to national prosecutors were simple in the Commission Proposal; those we find in the EPPO Regulation, as ultimately adopted, are highly complicated. This is likely due to the Office's different structure in the proposal and the Regulation.

In particular, in the Commission Proposal, a case within the EPPO's jurisdiction was to be referred to national prosecutors only where the alleged offence was minor. ${ }^{13}$ However, as

Truly European Prosecution Service?', New Journal of European Criminal Law (NJECL) 4(1-2) (2013), pp. 7-21 and note 21. With regard to the prospective models for the EPPO, see K. Ligeti, 'The European Public Prosecutor's Office: Which Model?', in A. Klip, ed., Substantive Criminal of the European Union (Antwerp: Maklu, 2011), p. 62.

12. M. Caianiello, 'The Proposal for a Regulation on the Establishment of an European Public Prosecutor's Office', pp. 119-120.

13. The definition of 'minor offence' in the PIF context is now set out in Article 7 of the Directive 2017/1371/EU, approved on 5 July 2017, on the fight against fraud to the Union's financial interests by means of criminal law on the fight against fraud to the Union's financial interests by means of criminal law, that is meant to replace the 1995 PFI Convention. The Directive follows the logic of the PIF Convention. The PIF Convention provides that criminal conduct affecting the Union budget shall be punishable by effective, proportionate and dissuasive criminal penalties and that other, noncriminal sanctions could be provided for minor cases below a threshold of 4000 ECU40, and Article 7(1) of the Directive similarly stipulates an obligation to punish the offences listed in Articles 3, 4 and 5 by effective, proportionate and dissuasive criminal sanctions. Article 7(4), however, raises the criminalization threshold to $€ 10,000$. On the new 
commentators pointed out, the Proposal did not define what constituted a 'minor' offence, leaving it to the Court of Justice of the European Union (CJEU; or to further legislation) to flesh this out in case law. Further, referring a case to national prosecutors did not prevent or limit national prosecution. On the contrary, the case was so referred precisely for the national prosecutors to investigate and prosecute it properly. Still further, the provisions concerning the 'right of evocation' of a case by the EPPO (i.e. the EPPO's right to take over an investigation), both when the investigations started at national level and when they had been referred by the EPPO to national prosecutors, were vague and appeared to leave the EPPO with an unusually broad discretion. ${ }^{14}$

\section{The EPPO regulation}

Things have become much more complicated in the EPPO Regulation. First, as is the case for all important decisions concerning prosecution, it is the new collegiate body (the Permanent Chamber) which decides whether or not to refer a case to national prosecutors. Second, the Regulation sets out elaborate criteria as to the decision. Starting with the EPPO's competence, Article 22 provides that the EPPO has no jurisdiction if the harm caused to the financial interests of the Union is below $€ 10,000$ (Article 25(2)). This is subject to exceptions where the case has repercussions at Union level which require an investigation to be conducted by the EPPO or where officials or other servants of the EU, or members of the Institutions could be suspected of having committed the offence. Moreover, according to Article 25(3), after consultation with national authorities, the EPPO shall refrain from exercising its competence if:

(a) the maximum sanction provided for by national law for an offence falling within the scope of Article 22(1) is equal to or less severe than the maximum sanction for an inextricably linked offence as referred to in Article 22(3) unless the latter offence has been instrumental to commit the offence falling within the scope of Article 22(1); or

(b) there is a reason to assume that the damage caused or likely to be caused, to the Union's financial interests by an offence as referred to in Article 22 does not exceed the damage caused, or likely to be caused to another victim.

Another complex provision is found in Article 27(8) of the EPPO Regulation, which prescribes that when an offence has caused or is likely to cause damage to the Union's financial interests for less than $€ 100,000$, the College may judge that, because of the degree of seriousness of the alleged offence or the complexity of the proceedings, there is no need to investigate or to prosecute at Union level. In such a case, it must issue general guidelines allowing the EDPs to decide, independently and without undue delay, not to evoke the case. The guidelines must define with all the necessary precision the cases to which they apply, establishing clear criteria, taking specifically into account the nature of the offence, the urgency of the situation and the commitment of the competent national authorities to take all necessary measures in order to allow a full recovery of the damage to the Union's financial interests.

PIF Directive, see Adam Juszczak \& Elisa Sason, The Directive on the Fight against Fraud to the Union's Financial Interests by means of Criminal Law (PIF Directive) - Laying Down the Foundation for a Better Protection of the Union's Financial Interests?, Eurocrim 2/2017, pp. 80-87.

14. See M. Caianiello, 'The Proposal for a Regulation on the Establishment of an European Public Prosecutor's Office', p. 121, on the criterion of crimes 'inextricably linked'. 


\section{The risk of a potential prolonged state of uncertainty}

The aforementioned provisions of the EPPO Regulation clearly give rise to a very complicated framework. Under this, a case could be initially considered not serious enough for the EPPO to investigate and/or prosecute, before subsequently becoming sufficiently grave to justify the same. What if, for example, a crime affecting the financial interests of the EU seems to have caused less than $€ 100,000$ of damage and, after more thorough investigations, it emerged that the harm was above that threshold? Similarly (although this appears less likely), the harm a crime caused to the EU's financial interest might at first appear less than $€ 10,000$ before subsequently being found to be far higher. Of course, the converse could also occur (i.e. crimes may turn out to be far less serious than initially appeared).

In all these circumstances, there is room for uncertainty, which may risk that a case remains disputed between the national and EU level throughout the investigation. The EPPO might first decide to refer a case to national authorities before, on reconsideration, deciding it wants the case back. It is true that the decision to evoke a case can only be taken when a national investigation has not already concluded and when an indictment has not yet been submitted to a court (Article 26(7)). However, this potential for a prolonged status of uncertainty - arising from the aforementioned provisions - undermines the EPPO system. Moreover, there is room for 'positive' or 'negative' conflicts of jurisdiction, ${ }^{15}$ with the EPPO claiming that the crimes committed are not sufficiently serious to justify its action and the national law enforcement agencies affirming the opposite (and vice versa).

Difficult as the above-mentioned problem is, it is not the main one. The criteria in Article 25(3), cited above, give a broad margin of appreciation to the EPPO. For example, how does one define the 'maximum sanction'? Should the EPPO take into consideration only the main punishment (presumably imprisonment), or should they also take into account other forms of punishment which are frequently applied alongside imprisonment? What if, for example, the Article 22(1) offence has a slightly higher imprisonment limit than the Article 22(3) one, but the Article 22(3) alone also gives rise to severe fines or other forms of sanctions, such as disqualification, prohibition to exercise certain professions, ineligibility for certain public charges and so on?

Still more complex are the other two concepts used in Article 25(3). When is an Article 22(3) offence 'instrumental' to an Article 22(1) one? And what about the criterion provided for in Article 25(3)(b), one that appears to raise the spectre of parties raising continuous procedural exceptions? Arguably, these criteria are incompatible with Article 47(2) of the Charter of Fundamental Rights of the EU (CFR), which requires that the defendant be informed in advance the jurisdiction before

15. Conflicts of jurisdiction represent a constant problem in the multilevel EU criminal justice system. However, while we may tolerate such conflicts between national authorities in transnational cases (horizontal cooperation), they seems far less acceptable in a hierarchical, federalized model such as the EPPO. See, on the matter of conflict of jurisdiction, M. Kaiafa-Gbandi, 'Jurisdictional Conflicts in Criminal Matters and their Settlement within EU's Supranational Settings', European Criminal Law Review (EuCLR) (2017), pp. 30-45; M. Böse, 'Choice of Forum and Jurisdiction', in M. Luchtmann, ed., Choice of Forum in Cooperation Against EU Financial Crime (Den Haag: Eleven International Publishing, 2012), p. 73; H.H. Herrnfeld, 'Mechanisms for Settling Conflicts of Jurisdiction', in M. Luchtmann, ed., Choice of Forum in Cooperation Against EU Financial Crime, p. 185; N.I. Thorhauer, 'Conflicts of Jurisdiction in Cross-Border Criminal Cases in the Area of Freedom, Security, and Justice. Risk and Opportunities from an Individual Rights-Oriented Perspective', New Journal of European Criminal Law (NJECL) 6(1) (2015), pp. 78-101; G. Coffey, 'Resolving Conflicts of Jurisdiction in Criminal Proceedings: Interpreting Ne Bis In Idem in Conjunction with the Principle of Complementarity', New Journal of European Criminal Law (NJECL) 4(1-2) (2013), p. 59 et seq. 
which they will be tried ('an independent and impartial tribunal previously established by the law'). ${ }^{16}$ The criteria laid down in the EPPO Council's Proposal do not seem clear enough to satisfy the principle expressed in the CFR.

\section{The provisions concerning the dismissal of the case}

Under the Commission Proposal, a case could be entirely dismissed (i.e. closed with neither a prosecution nor a referral to national authorities) in two cases: first, in a number of situations where, in short, there were not sufficient grounds to prosecute; second, where the case concluded by a simplified prosecution procedure. These have not substantially changed in the final Regulation.

With regard to the first set of cases, Article 39 of the Regulation provides that a case shall be dismissed where the suspect has died or (in the case of a company) been wound-up, the suspect is insane, or the conduct subject to investigation does not amount to a criminal offence. The same is true where amnesty has been granted to the suspect, the suspect has immunity that has not been lifted, and when the relevant national statutory limitation period has expired. Prosecution is similarly barred in cases of ne bis in idem, that is when the suspected person has already been finally acquitted or convicted of the same facts within the Union or the case has been disposed of by plea agreement (the so called 'simplified procedures'), in accordance with Article 40. Finally, the case can be dismissed for lack of relevant evidence.

What has changed is how this decision is taken. The Regulation provides for central decisionmaking: neither the ESP nor the EDP is allowed to adopt that decision, the power being attributed to the competent Permanent Chamber. This solution is a more thoughtful system than that provided by the 2013 Proposal, where the dismissal was decided by the EPPO. Further, Article 28 of the 2013 Proposal simply referred to the EPPO as such, causing some commentators to assume that the actual decision would be taken by the EDP (and simply validated by the central office). On the contrary, the attribution of the decision to the Permanent Chambers in the Regulation (Article 10(3)(c)) means that any given prosecutor is prevented from dismissing a case, because the decision requires the agreement of three prosecutors. In practice, this entails a stricter control of the decision to dismiss. As such, the new dismissal's procedure seems more closely aligned with the legality than to the opportunity principle. This is not to say that the EPPO Regulation is committed to a model of pure mandatory prosecution. The criteria provided by the law, in fact, leave room for some discretion. However, as outlined, this is subject to strict control, requiring as it does the approval of the three Members of the relevant Permanent Chamber.

Under the Regulation, only one decision is taken jointly by the Permanent Chamber and the EDP: the evocation of the case, as a rule attributed to the single EDP, but open to the intervention of the panel of the Permanent Chamber. According to Article 27(6), second paragraph:

Where a European Delegated Prosecutor, who has received the information in accordance with Article 24(2), considers not to exercise the right of evocation, he/she shall inform the competent Permanent

16. See, in this sense, M. Panzavolta, Choice of Forum and the Lawful Judge Concept, in M. Luchtmann, ed., Choice of Forum in Cooperation Against EU Financial Crime, p. 143. 
Chamber through the European Prosecutor of his/her Member State with a view to enabling the

Permanent Chamber to take a decision in accordance with Article 10(4).

Finally, the Regulation provides additional, specific rules for reopening of the case after its previous dismissal. The dismissal of a case does not bar further investigation. However, to reopen the case, it is necessary that new facts, not known to the EPPO at the time of the decision, come to light. A decision to reopen the investigation is taken by the competent Permanent Chamber. This again makes clear that the destiny of EPPO investigations - their initiation, their closure (both in the case of prosecution and dismissal) and their reopening - is wholly under the control of the Permanent Chamber.

\section{Res iudicata?}

Dismissal of a case under Article 40 of the EPPO Regulation does not trigger the protection of ne bis in idem, except in a certain number of specific cases. However, it does limit the possibility for further investigations by the EPPO; in other words, the decision to reopen the case is not at the pure and unlimited discretion of any single prosecutor. ${ }^{17}$

Article 39(2) provides:

A decision in accordance with paragraph 1 shall not bar further investigations on the basis of new facts which were not known to the EPPO at the time of the decision and which become known after the decision. The decision to reopen investigations on the basis of such new facts shall be taken by the competent Permanent Chamber.

Apart from the control exercised by the Permanent Chambers (see supra, §IV), this provision prevents the EPPO from investigating (and, a fortiori, prosecuting) unless new facts become known after the dismissal of a case that call for further action. This means that, although not equivalent to the ne bis in idem effect, some provisional estoppel is triggered by the decision to dismiss the investigations.

This raises two sets of questions:

\section{(a) Questions concerning 'new facts'}

Three questions arise. First, what constitute new facts within the meaning of Article 39(2)? In particular, how pertinent or persuasive do they need to be so as to permit the reopening of a case?

The second question concerns how the EPPO becomes aware of the new facts. What if, in particular, the prosecutor continues to investigate following dismissal, in violation of the Regulation, and ends up finding new facts? Could such facts, illegally discovered, be used to start a new investigation (or to justify the decision to prosecute)?

The third question concerns the scope of the prohibition. It is limited to investigations, or does it also apply to prosecutions? In other words, could the EPPO legally prosecute a case that has been dismissed, in the absence of new facts?

17. Notably, this limit on the reopening of the case was only introduced in the Council's Proposal. The Commission's Proposal contained no limit on the EPPO reopening the case once it has been dismissed. 
With regard to the first question (the nature of the new facts), it seems reasonable to assume that they need to have some prima facie evidentiary value. If a case was dismissed as prosecution 'ha[d] become impossible' because of lack of relevant evidence (Article 39(1)(g)), then the new facts that allow the reopening of the case must be of such value to make the prosecution 'possible'. The problem is that no substantive criteria are provided for the decision to investigate or prosecute. This is probably because EPPO must prosecute before national courts pursuant to national law, and each jurisdiction will have specific criteria in this respect (e.g. probable cause, reasonable suspicion, reasonable grounds to believe and so on). Still, the most reasonable interpretation seems to be that where the case was dropped for lack of evidence, the new facts need to be of such relevance, alone or with the previously-known facts, to meet the criteria provided by the national legislation to justify investigation and/or prosecution. In other words, the new facts need to potentially justify a prosecution according to the national provisions.

With regard to the second problem, the answer is implicit in the law. Information or evidence collected without lawful authority cannot be used to justify the reopening of the case. It follows that the EPPO may only reopen an investigation on the basis of evidence drawn to its attention by other sources and lawfully collected by the same. Possible sources include an OLAF investigation, national prosecutors' investigations, not involved in the dismissed case, or indeed EPPO itself where the facts were collected in the course of a distinct, lawful investigation.

This point serves to underline the limited nature of the prohibition of further investigation caused by dismissing a case. This simply prevents the EPPO from reinvestigating the same person for the same facts. It does not apply to EPPO's other investigations, to national authorities or to other EU authorities.

The balance struck by Article 39(2) is consistent with the European Court of Justice (ECJ)'s ruling with respect to the ne bis in idem principle under the Schengen Convention in Kossowski. There, the ECJ held that where a second prosecutor was considering reopening a previouslyinvestigated case, they had to consider two factors: first, whether the first investigation 'does indeed constitute a final decision including a determination as to the merits of the case', ${ }^{18}$ and second, if a detailed investigation was undertaken during the first time. This assessment is for the second prosecutor. If either or both of these criteria is not met, the case can be lawfully reopened. ${ }^{19}$ This is analogous to Article 39(2). If new facts come to light, the first inquiry can arguably be considered incomplete, by analogy with the second Kossowski criterion. The Kossowski case also raises the interesting question of whether and when the EPPO should be able to investigate a case dismissed before a national jurisdiction, given the differences between the mutual trust system at issue in Kossowski and the multilevel, hierarchical system established by the EPPO Regulation. ${ }^{20}$

Turning to the third question, the limitation should apply to both investigation and prosecution. If only investigations were prevented, EPPO prosecutors could easily circumvent the prohibition by simply indicting the suspect, and subsequently collecting evidence concerning new facts.

18. ECJ, 29 June 2016, Kossowski, C-486/14 paras 51 and 52. See A. Marletta, 'A New Course for Mutual Trust in the AFSJ? Transnational ne Bis in Idem and the Determination of the Merits of the Case in Kossowski', New Journal of European Criminal Law (NJECL) 8(2) (2017), pp. 108-115.

19. Kossowski, para 53.

20. In particular, Kossowski states that these two criteria should be investigated based only on the documents provided by the first Member State, in the light of the principle of mutual trust. It might be argued that the same limit should apply to the EPPO. However, given the EPPO's superior hierarchical position, it might be countered that the EPPO should have greater scope to investigate or reconsider the Member State's first decision (i.e. going beyond the documents provided by the Member State). 
(b) Special procedures and limitation provisions

Given that the Article 39(2) places only partial limits on further investigations or prosecutions even where a case is dismissed for lack of evidence, one might wonder in what situations the ne bis in idem bar does bite. The main provision on which the ne bis in idem effect bites is the dismissal of a case using the simplified procedure under Article 40. Here, the ECJ's ne bis in idem jurisprudence in the Schengen context plainly applies by analogy. As the Court held in C-187/01 Gözuütok and Bruügge ${ }^{21}$ :

The ne bis in idem principle, laid down in Article 54 of the Convention implementing the Schengen Agreement $[. .$.$] also applies to procedures whereby further prosecution is barred, such as the proce-$ dures at issue in the main actions, by which the Public Prosecutor of a Member State discontinues criminal proceedings brought in that State, without the involvement of a court, once the accused has fulfilled certain obligations and, in particular, has paid a certain sum of money determined by the Public Prosecutor.

The Court further observed that:

the objective of which is to ensure that no one is prosecuted on the same facts in several Member States on account of his having exercised his right to freedom of movement, cannot play a useful role in bringing about the full attainment of that objective unless it also applies to decisions definitively discontinuing prosecutions in a Member State, even where such decisions are adopted without the involvement of a court and do not take the form of a judicial decision.

The same reasoning applies to a plea agreement with the EPPO.

Another case in which ne bis in idem should apply is when the case has been dismissed because of the expiration of the relevant national statutory limitation period for prosecution. In such circumstances, the Court's reasoning in C-467/04 Gasparini should be applied, according to which ne bis in idem operates 'in respect of a decision of a court of a Contracting State, made after criminal proceedings have been brought, by which the accused is acquitted finally because prosecution of the offence is time-barred'. ${ }^{22}$

In this respect, a brief aside on the Taricco saga is necessary. ${ }^{23}$ That saga does not alter the above-mentioned conclusion. It is true that in its 2015 Taricco decision, the ECJ held that national

21. See J.A.E. Vervaele, 'The Transnational ne Bis in Idem Principle in the EU, Mutual Recognition and Equivalent Protection of Human Rights', Utrecht Law Review (ULR) 1(2) (2005), pp. 100-118. More in general on the ne bis in idem principle see V.B. Bockel, The ne bis in idem principle in EU law (Amsterdam: Kluwer Law International edition, 2010), p. 29s; C. Van Den Wyngaert and G Stessens, 'The International Non Bis in Idem Principle: Resolving some of the Unanswered Questions', International and Comparative Law Quarterly (ICLQ) 48(4) (1999), pp. 779-804; J.A.E. Vervaele, 'Ne Bis In Idem: Towards a Transnational Constitutional Principle in the EU?', Utrecht Law Review (ULR) 9(4) (2013), p. 211.

22. See on the Gasparini case M. Wasmeier, 'The Principle of ne Bis in Idem', Révue Internationale de Droit Pénale (RIDP) 77 (2006), p. 126. See also V. Mitsilegas, EU Criminal Law after Lisbon: Rights, Trust and the Transformation of Justice in Europe (Oxford and Portland, OR: Hart Publishing, 2016) pos. n. 3287 (digital edition).

23. ECJ, 8 September 2015 (C-105/14), Taricco and others. For an analysis of this decision, see A. Klip, European Criminal Law. An Integrative Approach, 3rd ed. (Antwerp: Intersentia, 2016), pp. 75-80. See also M. Caianiello, 'Dum Romae (et Brucsellae) Consulitur . . Some Considerations on the Taricco Judgment and Its Consequences at National and European Level', European Journal of Crime, Criminal Law and Criminal Justice (EJCCL) 24 (2016), pp. 1-17; E. Billis, 'The European Court of Justice: A “Quasi-Constitutional Court” in Criminal Matters? The Taricco Judgment 
courts must disapply limitation provisions that prevent the effective, proportionate and dissuasive protection of the financial interests of the EU. However, it does not follow that the EPPO can reopen a case dismissed by a national court because of the expiry of a national limitation period terms in order to protect in full the Union's financial interests. Unlike in Taricco, this would bring into play Article $50 \mathrm{CFR}$ (the ne bis in idem principle), which has equal value to Article $325 \mathrm{TFEU}$ and would prevent such an undermining of the Defendant's rights. This conclusion is reinforced by the Court's decision in Taricco II in 2017, where the Court qualified Taricco by reaffirming (and, in the case, extending) the principle that Article 325 TFEU was subject to values such as the legality principle. ${ }^{24}$ What holds for Article 49 CFR (the legality principle) should hold too for Article 50 CFR (ne bis in idem). In other words, when a case has been closed before a national jurisdiction because of limitation period provisions that comply with the Taricco case law, the EPPO cannot override this by invoking Article 325 TFEU.

Similarly, ne bis in idem would prevent the reopening of cases already finally disposed of in relation to the same acts. It should also apply to dismissals based on amnesty and immunity, unless such immunity has since been lifted.

This leaves one dismissal ground where 'new facts' might operate to lift the bar: the 'insanity of the suspect or accused person'. On a proper analysis, this legal provision really amounts to a case of lack of evidence, namely an inability to fulfil certain (mental) elements of the offence the prosecution must prove. If new facts suggest the defendant was of sufficiently sound mind at the moment they allegedly committed the crime, the Permanent Chamber should authorize further action.

\section{A tempered discretionary system}

As set out earlier, the provisions concerning dismissal or referral of a case have significantly changed since the first Proposal of 2013. This raises the question of how the exercise of these provisions will be judicially reviewed.

With regard to referral of a case to national prosecutors, the rules set out in the EPPO Regulation are more complex and more discretionary than those in the proposal, giving rise to a risk of conflicts of jurisdiction. It will be for the EU's court of last instance - the ECJ - to reduce the scope of this discretion, and so the risk of arbitrariness, by its case law so as to remedy the provisions' poor drafting. In this way, the counterweight provided by the Treaties and Regulation - namely the role of the Court in interpreting the provisions - has the potential to lead to an acceptable level of predictability to the system in accordance with the principle of the judge pre-established by law which was mentioned with reference to Article $47 \mathrm{CFR} .^{25}$

and Its Shortcomings', New Journal of European Criminal Law (NJECL) 7(1) (2016), p. 20s; F. Giuffrida, 'The Limitation Period of Crimes: Same Old Italian Story, New Intriguing European Answers: Case note on C-105/14, Taricco', New Journal of European Criminal Law ((NJECL) 7(1) (2016), pp. 100-112.

24. ECJ, 5 December 2017 (C-42/17), M.A.S. and M.B. See M. Bassini and O. Pollicino, 'Defusing the Taricco Bomb through Fostering Constitutional Tolerance: All Roads lead to Rome', Diritto penale contemporaneo. Available at: www.penalecontemporaneo.it (accessed 11 December 2017); M. Krajewski, 'Conditional' Primacy of EU Law and its Deliberative Value: An Imperfect Illustration from Taricco II. Available at: http://europeanlawblog.eu/tag/case-c4217-m-a-s-m-b-taricco-ii/ (accessed 18 December 2017). See also B. Budinska and Z. Vikarska, Criminal Law, Human Rights and Constitutional Pluralism: Two Views on Taricco II. Available at: http://eulawanalysis.blogspot.it/ 2017/12/criminal-law-human-rights-and.html (accessed 8 December 2017).

25. M. Luchtmann, 'Choice of Forum and the Prosecution of Cross-Border Crime in the European Union - What Role for the Legality Principle?', in M. Luchtmann, ed., Choice of Forum in Cooperation Against EU Financial Crime, p. 3; 
With respect to the dismissal of a case, the EPPO Regulation constructs a tempered discretionary system whereby the margin of appreciation granted to the EPPO is rather broad, though subject to the oversight of collegial bodies, the Permanent Chambers. The effects arising from dismissal depend on the grounds of dismissal. If lack of sufficient evidence is the ground, then a limited estoppel on further investigation arises, one that can be removed by the Permanent Chamber where new facts are discovered. As outlined above, such new facts must be discovered after the dismissal and in the course of a separate investigation. By contrast, the full force of ne bis in idem prevents further investigation or prosecution where a case concludes with a plea agreement (under Article 40). The same holds true for the other forms of dismissal described above, such as those based on the expiration of statutory limitation periods or immunities.

From a comparative perspective, one might observe that this tempered discretionary system is reminiscent of the institutional framework provided for by the Rome Statute of the International Criminal Court (ICC). There, decisions to drop investigations are regulated by flexible criteria (in fact, ones that are more flexible than those provided by the EPPO's Regulation), leaving a margin of appreciation to the Prosecutor. Nonetheless, even in the ICC system, the decision to drop a case can be reviewed by the Pre-trial Chamber ${ }^{26}$ and must be so reviewed when the ground for dropping the case is the interests of justice. ${ }^{27}$ There are, moreover, two main differences. The first concerns the body which controls the exercise of this discretion: a panel of judges at the ICC, but three prosecutors in the EPPO system. The ICC system's scrutiny over dismissal decisions seems - at least from an institutional perspective - more impartial, and in particular more hierarchical, than the EPPO's control. This difference reflects the limits of the EPPO itself which, unlike the ICC, is merely a prosecutorial body and does not incorporate a common EU criminal court.

Second, the estoppel on investigation arising from the dismissal of a case are perhaps better regulated in the EPPO system than the ICC's, as the former specifically distinguishes between final dismissals (on which ne bis in idem bites) from other reasons of dismissal (which give rise to a more limited estoppel, which may be removed by the relevant Permanent Chamber in certain circumstances). By contrast, in the ICC system, the Prosecutor is free to reopen the case if new facts or new information become available, without any requirement to seek authorization (Article 53(4) of the Rome Statute).

\section{Conclusion}

In conclusion, the EPPO Regulation envisages a system for dropping cases that is both balanced and merges different legal traditions' rules in an original way. As with many other aspects of the EPPO, the structural deficiencies this system suffers seem to stem mainly from the lack of a common judicial authority capable, at least as a last resort, of ensuring a certain level of uniformity in the system. In the long run, that limit needs to be overcome if the ultimate goal is to construct an effective common criminal justice system for the protection of the financial interests of the EU.

J.A.E. Vervaele, 'European Territoriality and Jurisdiction: The Protection of the EU's Financial Interests in Its Horizontal and Vertical (EPPO) Dimension', in M. Luchtmann, ed., Choice of Forum (2012), p. 167.

26. See C. Safferling, ed., International Criminal Procedure (Oxford, UK: Oxford University Press, 2012), pp. 139-141. See also K. Ambos, Treatise on International Criminal Law, Vol. III. (Oxford, UK: International Criminal Procedure, Oxford University Press, 2016), pp. 381-386; W.A. Schabas, The International Criminal Court. A Commentary on the Rome Statute (Oxford, UK: Oxford University Press, 2010), pp. 668-670.

27. K. Ambos, 'Treatise on International Criminal Law', pp. 387-391. 
With this in mind, one hopes that parties will make extensive use of Article 42(3) of the Regulation. This provision derogates from the general rule of Article 42(1), according to which EPPO actions are subject to national judicial review alone. It provides that an EPPO decision to drop a case is instead subject to review by the CJEU pursuant to an action for annulment in so far as they are contested directly on the basis of Union law. In this sense, Article 42(3) of the Regulation read with Article 263(4) TFEU provides that such a decision would be directly reviewed by the Court where (inter alia) a natural (or legal) person could show it was addressed to him or directly and individually concerned them. Defendants in EPPO proceedings should always be able to satisfy these criteria. More interestingly, victims are arguably directly and individually concerned by such a decision, and so have standing. Notably, the EPPO is required to inform the complainant both of the decision to initiate an investigation (Article 24(7)) and of its dismissal (Article 39(4)). Furthermore, recital 107 of the Regulation states that 'The EPPO should enable the institutions, bodies, offices or agencies of the Union and other victims to take appropriate measures'. Judicially reviewing the dismissal of a case is arguably an appropriate measure for the victim in this sense.

If the Court adopts the above interpretation, every decision by the EPPO to dismiss a case would be open to review by the CJEU where the dismissal was said to violate EU law. This is a first building block towards a real federal system where, ultimately, the CJEU becomes the common judicial authority required to build a truly federal criminal system. This role of the EU's central courts could fill the gaps and the uncertainties left in the EPPO Regulation and detailed above, and ultimately assist in giving consistency to the whole prosecutorial policy in the field of the protection of the financial interests of the Union. ${ }^{28}$ In this way, the EPPO would not only be subject to the rule of law, as Article 5 of the Regulation provides. It would also be instrumental in the enhancing that principle and its application throughout the EU - an outcome that would, after all, vindicate the struggle and efforts of a generation of lawyers over the past two decades to make the EPPO a reality.

\section{Author's note}

This article is a revised version of a speech presented at the Universidad Complutense in Madrid, Spain, on December 2015. The original version is published in the book edited by L. Bachmaier Winter, The European Public Prosecutor's Office: the challenges ahead, Springer, forthcoming.

\section{Declaration of conflicting interests}

The author(s) declared no potential conflicts of interest with respect to the research, authorship, and/or publication of this article.

\section{Funding}

The author(s) received no financial support for the research, authorship, and/or publication of this article.

28. As J. Vervaele observes, with regard to enforcement, 'In public law, there is a very strong relationship between the substantive norms on administrative irregularities and criminal (the jurisdiction to prescribe) and the applicable law and jurisdiction (the jurisdiction to enforce and the jurisdiction to adjudicate)'. J.A.E. Vervaele, European Criminal Justice in the post-Lisbon Area of Freedom, Security and Justice (Trento, Italy: University of Trento, 2014), p. 284. This leads inexorably to the conclusion that a common judicial institution is required to enforce EU criminal provisions. 